\title{
Pengaruh Manipulasi Sport Massage Terhadap Intensitas Nyeri Setelah Aktivitas Eksentrik
}

\author{
Mochamad Azhar Ilmi ${ }^{1}$, Bambang Purwanto ${ }^{2}$, Damayanti Tinduh ${ }^{3}$ \\ ${ }^{1,2}$ Ilmu Kesehatan Olahraga, Departemen Faal, Fakultas Kedokteran Universitas Airlangga \\ ${ }^{2}$ Departemen Rehabilitasi Medik, Fakultas Kedokteran Universitas Airlangga email : \\ 12azhar.ilmi.ai@gmail.com, ${ }^{2}$ bpaifo@gmail.com, ${ }^{3}$ daniellarosita@yahoo.com
}

\begin{abstract}
Abstrak
Aktivitas eksentrik adalah jenis aktivitas resistance yang sering menimbulkan rasa nyeri dan kerusakan otot. Jenis penelitian yang akan dilakukan adalah penelitian eksperimen, dengan desain penelitian randomized pre test and post test group design. Manipulasi sport massage diberikan 6 jam setelah aktivitas eksentrik. Manipulasi sport massage dibagi menjadi 4 kelompok, kelompok manipulasi effleurage, petrissage, shaking, tapotement dan 1 kelompok control. Pengkuran intensitas nyeri mengunakan kriteria objektif nyeri melalui visual analogue scale (VAS). Dari hasil penelitian diketahui bahwa pemberian manipulasi sport massage pada kelompok perlakuan manipulasi effleurage, petrissage, shaking, tapotement dan kontrol 6 jam setelah aktivitas eksentrik dapat menurunkan intensitas nyeri $(2,17 \pm 0,753 ; 1,50 \pm 0,837 ; 2,20 \pm 0,837 ; 1,40 \pm 0,548 ; 3,83 \pm 0,753)$ dengan nilai $p=0,001$ pada jam ke 24 .
\end{abstract}

Kata kunci : sport massage, aktivitas eksentrik, intensitas nyeri

\section{Pendahuluan}

Pengaruh negatif dari latihan seperti yang dikemukakan oleh Byrne et al., (2004) adalah latihan dapat merusak serabut otot yang ditunjukkan dengan ketidaknormalan fungsi otot, delayed onset muscle soreness (DOMS), peningkatan tingkat protein plasma, serum creatin kinase dalam darah, serta menurunnya kekuatan otot. Burnley et al. (2010) juga menyatakan bahwa gejalagejala kerusakan otot yang umumnya terjadi akibat latihan meliputi nyeri (soreness), penurunan kekuatan otot, range of motion $(\mathrm{ROM})$, peningkatan respons inflamasi, peningkatan jumlah serum creatine phosphokinase dalam darah.

Jenis latihan yang dapat merusak serabut otot adalah jenis latihan yang menggunakan tipe kontraksi otot secara eksentrik (Clarson et al., 2008). Latihan eksentrik merupakan salah satu jenis latihan tahanan (resistance) yang sering menimbulkan rasa nyeri dan kerusakan otot, hal ini dikarenakan saat melakukan latihan eksentrik otot mengalami pemanjangan yang maksimal guna menghasilkan daya yang maksimal (Burnley et al., 2010).

Sports massage (masase olahraga) merupakan salah satu modalitas terapi fisik yang digunakan oleh atlet untuk meningkatkan performa fisik, mencegah dan mengatasi cedera serta gangguan fisik lainnya akibat kerja fisik dengan intensitas tinggi (Arovah, 2016). Robertson et al., (2004) menyatakan bahwa sports massage banyak digunakan sebagai modalitas terapi fisik untuk pemulihan dari kelelahan dan cedera otot pada atlet. Secara fisiologis, sports massage terbukti dapat menurunkan denyut jantung, meningkatkan tekanan darah, meningkatkan sirkulasi darah dan limfe, mengurangi ketegangan otot, meningkatkan jangkauan gerak sendi dan mengurangi nyeri (Callaghan, 1993) serta menurunkan kadar enzim creatine kinase dalam darah (Smith et al., 1994). Manfaat 
fisiologis tersebut telah banyak digunakan atlet baik untuk mendukung performa fisik maupun untuk tujuan lain seperti pencegahan, terapi dan rehabilitasi cedera maupun dampak negatif dari olahraga.

Manipulasi ini digunakan untuk relaksasi, meredakan ketegangan otot, memperbaiki sirkulasi darah, dan rentang gerak sendi atau memperluas gerakan (Arovah, 2011). Manipulasi swedish massage yang biasa digunakan setelah aktivitas atau latihan adalah effleurage, petrissage, shaking, friction, dan tapotement (Moraska, 2005). Pada aplikasi praktek sports massage di lapangan, seringkali masseur menggunakan manipulasi lengkap untuk proses pemulihan dan pencegahan cedera setelah aktivitas fisik. Oleh karena itu penelitian ini dilakukan manipulasi sport massage mana yang paling efektif untuk perbaikan intensitas nyeri setelah aktivitas eksentrik.

\section{Metode Penelitian}

Jenis dan rancangan penelitian

Penelitian ini menggunakan metode penelitian berupa metode experimental dengan randomized group pre test and post test control design.

Subjek penelitian

Pemilihan subjek penelitian berdasarkan beberapa kriteria inklusi yakni berjenis kelamin laki-laki, usia antara 21-24 tahun, tidak melakukan aktivitas eksentrik menjelang penelitian (3 hari sebelum penelitian) serta memiliki indeks massa tubuh (IMT) yang normal. Dan berdasarkan kriteria eksklusi yakni mengkonsumsi obatobatan minimal 1 minggu sebelum penelitian, telah terbiasa menjalani aktivitas resistance minimal selama 6 bulan sebelumnya, mengalami cedera otot yang serius.

Protokol aktivitas eksentrik

Subjek penelitian dalam kelompok perlakuan dan kontrol untuk latihan akut akan menjalani kondisioning terlebih dahulu selama 1 minggu. Kondisioning ini berupa arahan untuk tidak mengkonsumsi obat obatan, tidak melakukan aktivitas eksentrik, Setelah masa kondisioning selesai, maka subjek penelitian pada semua kelompok perlakuan melakukan latihan akut, yakni aktivitas eksentrik berupa drop jumps (naik turun bangku setinggi 0,5 meter) dengan jumlah 10 set, 1 set terdiri dari 10 repetisi dimana antar set melakukan recovery selama 1 menit.

\section{Protokol sport massage}

Untuk kelompok perlakuan, yakni kelompok pertama, kedua, ketiga dan keempat, subjek akan diberikan perlakuan manipulasi sport masage pada otot tungkai (ekstremitas bawah), dengan rincian perlakuan manipulasi sport masage pada otot tungkai sebagai berikut:

1) Kelompok K1 dengan manipulasi effleurage pada otot-otot paha depan belakang, lutut depan belakang, betis depan belakang, tumit dan punggung kaki dengan durasi waktu 20 menit

2) Kelompok K2 dengan manipulasi petrissage pada otot-otot paha depan belakang, lutut depan belakang, betis depan belakang, tumit dan punggung kaki dengan durasi waktu 20 menit

3) Kelompok K3 dengan manipulasi shaking pada otot-otot paha depan belakang, lutut depan belakang, betis depan belakang, tumit dan punggung kaki dengan durasi waktu 20 menit

4) Kelompok K4 dengan manipulasi tapotement pada otot-otot paha depan belakang, lutut depan belakang, betis depan belakang, tumit dan punggung kaki dengan durasi waktu 20 menit

5) Dari masing-masing kelompok dengan manipulasi yang berbeda, pelaksanaan prosedur sport massage dilakukan dari tungkai sebelah kiri terlebih dahulu, selanjutnya tungkai sebelah kanan.

Pengukuran intensitas nyeri

Pengukuran intensitas nyeri yang timbul akan diukur keesokan harinya setelah 24 jam dengan Visual Analogue Scale (VAS), dimana angka 0 menggambarkan rasa tidak nyeri dan angka 1-10 menggambarkan rasa nyeri yang hebat.

\section{Hasil dan Pembahasan}

Jumlah sampel penelitian ini berjumlah 30 orang yang terbagi menjadi 5 kelompok, masing masing kelompok terdiri dari 6 orang, dimana 4 kelompok diberikan perlakuan manipulasi sport massage (effleurage, petrissage, shaking, tapotement) dan 1 kelompok kontrol (tidak diberikan 
perlakuan manipulasi sport massage). Namun pada proses pengambilan data, ada kelompok perlakuan yang mengalami drop out 2 orang, yakni pada kelompok perlakuan 3 dan 4 masing masing 1 orang.

Tabel 1 Analisa Deskriptif Usia, Berat Badan, Tinggi Badan, dan IMT Subjek Penelitian, Tahun 2018

\begin{tabular}{|c|c|c|c|c|c|c|}
\hline Variabel & $\begin{array}{c}\text { K1 (6) } \\
\text { Rerata } \\
\pm \text { SD }\end{array}$ & $\begin{array}{c}\text { K2 (6) } \\
\text { Rerata } \\
\pm \text { SD }\end{array}$ & $\begin{array}{c}\text { K3 (6) } \\
\text { Rerata } \\
\pm \text { SD }\end{array}$ & $\begin{array}{c}\text { K4 (6) } \\
\text { Rerata } \\
\pm \text { SD }\end{array}$ & $\begin{array}{c}\text { K5 (6) } \\
\text { Rerata } \\
\pm \text { SD }\end{array}$ & $\mathbf{p}$ \\
\hline $\begin{array}{l}\text { Usia } \\
\text { (tahun) }\end{array}$ & $\begin{array}{c}19,83 \pm \\
0,753\end{array}$ & $\begin{array}{c}20,33 \pm \\
0,516\end{array}$ & $\begin{array}{c}20,17 \pm \\
0,408\end{array}$ & $\begin{array}{c}19,83 \pm \\
0,983\end{array}$ & $\begin{array}{c}20,67 \pm \\
0,516\end{array}$ & 0,006 \\
\hline $\begin{array}{l}\text { Berat } \\
\text { badan }(\mathrm{kg})\end{array}$ & $\begin{array}{c}61,66 \pm \\
3,141\end{array}$ & $\begin{array}{c}58,16 \pm \\
3,544\end{array}$ & $\begin{array}{c}59,83 \pm \\
3,060\end{array}$ & $\begin{array}{c}61,83 \pm \\
2,926\end{array}$ & $\begin{array}{c}61,66 \pm \\
3,723\end{array}$ & $0,950 *$ \\
\hline $\begin{array}{l}\text { Tinggi } \\
\text { badan }(\mathrm{m})\end{array}$ & $\begin{array}{c}1,69 \pm \\
0,027\end{array}$ & $\begin{array}{l}1,67 \pm \\
0,009\end{array}$ & $\begin{array}{l}1,70 \pm \\
0,028\end{array}$ & $\begin{array}{c}1,70 \pm \\
0,048\end{array}$ & $\begin{array}{c}1,69 \\
\pm 0,030\end{array}$ & 0,026 \\
\hline $\begin{array}{l}\text { IMT } \\
\left(\mathrm{kg} / \mathrm{m}^{2}\right)\end{array}$ & $\begin{array}{c}21,50 \pm \\
1,120 \\
\end{array}$ & $\begin{array}{c}20,70 \pm \\
1,020 \\
\end{array}$ & $\begin{array}{c}20,58 \pm \\
0,688\end{array}$ & $\begin{array}{c}21,31 \pm \\
0,446\end{array}$ & $\begin{array}{c}21,37 \pm \\
0,826\end{array}$ & $0,746^{*}$ \\
\hline
\end{tabular}

Keterangan :

* : Berdistribusi Homogen

Tabel 2 Rerata Intensitas Nyeri dan Standar Deviasi Kelompok Perlakuan dan Kontrol

\begin{tabular}{|c|c|c|c|c|c|}
\hline Kelompok & $\mathrm{N}$ & $\begin{array}{c}\text { Intensitas } \\
\text { Nyeri }\end{array}$ & $\begin{array}{c}\text { Uji } \\
\text { Normalitas }\end{array}$ & $\begin{array}{c}\text { Uji } \\
\text { Homogenitas }\end{array}$ & $\mathrm{p}$ (sig) \\
\hline K1 & 6 & $2,17 \pm 0,753$ & 0,314 & \multirow{5}{*}{0,817} & \multirow{5}{*}{$0,001 *$} \\
\hline K2 & 6 & $1,50 \pm 0,837$ & 0,325 & & \\
\hline K3 & 5 & $2,20 \pm 0,837$ & 0,314 & & \\
\hline K4 & 5 & $1,40 \pm 0,548$ & 0,325 & & \\
\hline K5 & 6 & $3,83 \pm 0,753$ & 0,314 & & \\
\hline
\end{tabular}

Keterangan :

$\mathrm{K} 1$ : Kelompok perlakuan effleurage

K2 : Kelompok perlakuan petrissage

$\mathrm{K} 3$ : Kelompok perlakuan shaking

K4 : Kelompok perlakuan tapotement

K5 : Kelompok kontrol (tanpa perlakuan)

* : Nilai signifikan

Dengan uji Manova, pada seluruh kelompok subjek penelitian terhadap intensitas nyeri diperoleh nilai $\mathrm{p}=0,001<$ 0,05 , sehingga dapat dikatakan terdapat pengaruh yang bermakna setelah pemberian manipulasi sport massage terhadap intensitas nyeri setelah aktivitas eksentrik pada subjek penelitian

Tabel 3 Nilai p Value Uji LSD Pada Intensitas Nyeri, Tahun 2018

\begin{tabular}{|c|c|c|c|c|c|}
\hline \\
\hline Kelompok & K1 & $\mathrm{K} 2$ & K3 & $\mathrm{K} 4$ & K5 \\
\hline $\mathrm{K} 1$ & - & 0,699 & 0,941 & 0,712 & $0,001 *$ \\
\hline K2 & 0,699 & - & 0,658 & 1,000 & $0,000 *$ \\
\hline K3 & 0,941 & 0,658 & - & 0,672 & $0,001 *$ \\
\hline $\mathrm{K} 4$ & 0,712 & 1,000 & 0,672 & - & $0,000^{*}$ \\
\hline $\mathrm{K} 5$ & $0,001 *$ & $0,000 *$ & $0,001 *$ & $0,000^{*}$ & - \\
\hline
\end{tabular}

Keterangan :

*: Nilai signifikan
Gambar 1 Grafik Rerata Intensitas Nyeri Pada Seluruh Subjek Penelitian, Tahun 2018

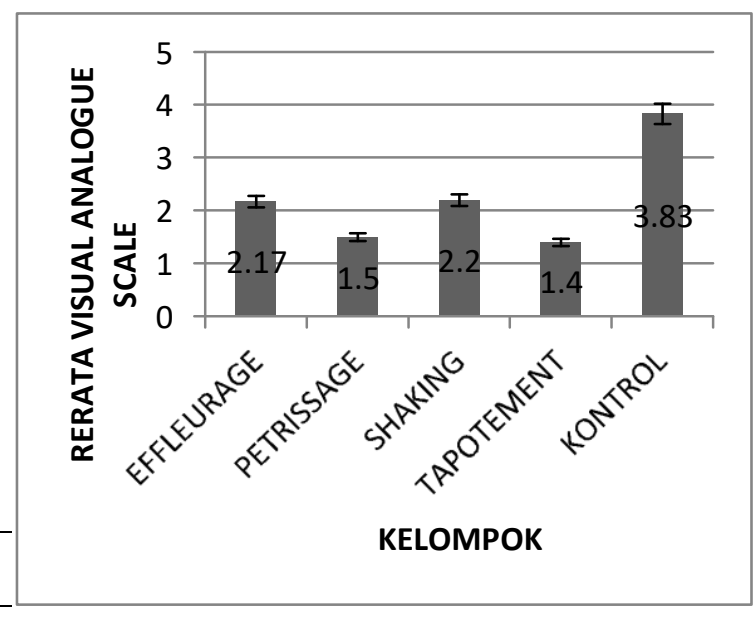

Dari data intensitas nyeri yang didapatkan pada seluruh kelompok pada peneilitian ini, didapatkan gambaran yang cukup nyata bahwa semua kelompok manipulasi sport massage baik manipulasi effleurage, petrissage, shaking, dan tapotement dapat menurunkan intensitas nyeri setelah aktivitas eksentrik, dengan berturut-turut manipulasi yang paling berdampak baik dengan menurunkan intensitas nyeri sebagai berikut, manipulasi tapotement, petrissage, effleurage, dan shaking.

\section{Mekanisme Kerja Sport Massage dalam Menurunkan Intensitas Nyeri Setelah Aktivitas Eksentrik}

Exercise-induced muscle damaged atau kerusakan otot akibat latihan merupakan fenomena yang umum terjadi setelah latihan yang tidak terbiasa atau latihan dengan intensitas dan durasi yang meningkat (Byrne et al, 2004). Kerusakan otot merupakan kegagalan setiap tingkat mempertahankan keseimbangan antara paparan stres dengan respon terhadap stres. Kegagalan di tingkat atomik menyebabkan kerusakan di tingkat molekuler, kegagalan di tingkat molekul menyebabkan kerusakan di tingkat seluler dan kegagalan di tingkat 
seluler menyebabkan kerusakan di tingkat jaringan. (Purwanto, 2013).

Jenis latihan yang dapat merusak serabut otot adalah jenis latihan yang menggunakan tipe kontraksi otot secara eksentrik (Clarson et al., 2008). Nyeri otot dengan hilangnya fungsi setelah latihan eksentrik lebih umumnya dikenal (DOMS) (Trenell et al., 2006). DOMS fokus pada tingkat tegangan yang irreversibel selama sarkomer mengalami kontraksi eksentrik, menghasilkan kerusakan komponen pada sarkomer. Retikulum sarkoplasma mungkin menjadi terlampau panjang ketika kontraksi eksentrik sehingga menyebabkan substansi ion kalsium dilepaskan dari dalam retikulum sarkoplasma (Bubbico, 2010).

Rasa nyeri merupakan mekanisme pertahanan tubuh, timbul bila ada jaringan rusak dan hal ini akan menyebabkan individu bereaksi dengan memindahkan stimulus nyeri (Guyton \& Hall, 2006). Munculnya nyeri berkaitan erat dengan reseptor dan adanya rangsangan. Reseptor nyeri tersebar pada kulit dan mukosa dimana reseptor nyeri memberikan respon jika adanya stimulasi atau rangsangan. Stimulasi tersebut dapat berupa zat kimia seperti histamine, bradikinin, prostaglandin dan macam-macam asam yang terlepas apabila terdapat kerusakan pada jaringan akibat kekurangan oksigen. Stimulasi yang lain dapat berupa termal, listrik, atau mekanis (Smeltzer \& Bare, 2002).

Hasil yang didapatkan pada penelitian ini setelah 24 jam melakukan aktivitas eksentrik adalah pada kelompok kontrol (K5) menunjukan rerata intensitas nyeri yang paling tinggi dibandingkan kelompok perlakuan manipulasi effleurage $(K 1)$, petrissage (K2), shaking (K3), dan tapotement (K4). Hal ini menunjukkan bahwa manipulasi pada sport massage baik manipulasi effleurage (K1), petrissage (K2), shaking (K3), dan tapotement (K4) dapat menurunkan rasa nyeri setelah aktivitas eksentrik, dimana Kelompok perlakuan manipulasi tapotement (K4) menunjukkan jumlah rerata yang paling rendah diantara yang kelompok yang lain.

Penurunan rasa nyeri pada hasil penelitian diatas terjadi karena akibat dari peran masing-masing manipulasi sport massage. Efek refleks tersebut sebagai hasil dari pengaruh fisiologi sport massage yang mempengaruhi sistem hormonal dan saraf (Giam dan Teh, 1993). Ganong (1995) menyebutkan bahwa reseptor-reseptor atau saraf yang menerima ra ngsang yang terdapat di bawah kulit terdiri atas ujung saraf ruffini, diskus markel, badan meissner, badan pacini, ujung saraf krause, dan ujung saraf telanjang di antara sel-sel dalam jaringan. Reseptor-reseptor tersebut peka terhadap rangsangan berupa raba tekan (tekanan adalan rabaan yang ditekan agak lama), dingin, hangat dan nyeri.

Ilustrasi Gate Control Theory (Monsdragon, 2004) bahwa serabut nyeri membawa stimulasi nyeri ke otak lebih kecil dan perjalanan sensasinya lebih lambat daripada serabut sentuhan yang luas. Ketika sentuhan dan nyeri dirangsang bersama, sensasi sentuhan berjalan keotak menutup pintu gerbang dalam otak. Dengan adanya pijatan yang mempunyai efek distraksi juga dapat meningkatkan pembentukan endorphin dalam sistem kontrol desenden dan membuat relaksasi otot. Dapat juga digunakan dasar Opiate Endogenous Theory, dimana reseptor opiate yang berada pada otak dan spinal cord menentukan dimana sistem saraf pusat mengistirahatkan substansi morfin yang dinamakan endorphin dan enkephalin bila nyeri diterima. Opiate endogen ini dapat dirangsang pengeluaranya oleh stimulasi kulit melalui pijatan. Opiate reseptor ini berada pada ujung saraf sensori perifer.

Berdasar uji perbedaan Manova pada penelitian ini, terdapat perbedaan yang bermakna pada pemberian manipulasi sport massage antar seluruh kelompok kontrol dan perlakuan manipulasi sport massage, dan pada hasil uji Post Hoc LSD, didapatkan hasil beda antara kelompok kontrol (tanpa manipulasi) dengan kelompok perlakuan manipulasi sport massage, baik manipulasi effleurage, petrissage, shaking dan tapotement. Hal ini menandakan bahwa penurunan intensitas nyeri dipengaruhi oleh manipulasi effleurage, petrissage, shaking dan tapotement, dimana manipulasi tapotement memiliki pengaruh penurunan intensitas nyeri yang paling baik. Secara umum pemberian manipulasi sport massage merupakan bentuk upaya untuk mengurangi nyeri setelah latihan yang terjadi segera 
maupun beberapa saat setelah kerja fisik pada otot yang mengalami ketegangan (Hemmings et al., 2000). Penelitian membuktikan bahwa penggunaan sport massage setelah latihan mengurangi waktu pemulihan dan secara bermakna dapat mencegah nyeri DOMS (delayed onset of muscle soreness) setelah pertandingan (Hilbert et al., 2003).

Berdasarkan hasil penelitian dan teori yang telah dipaparkan di atas, peneliti berpendapat bahwa pemberian manipulasi sport massage setelah aktivitas eksentrik dapat menurunkan persepsi nyeri pada tungkai setelah aktivitas eksentrik, dimana semua keempat manipulasi sport massage baik effleurage, petrissage, shaking dan tapotement berdampak baik dalam menurunkan persepsi nyeri, dimana manipulasi tapotement memiliki pengaruh yang paling baik.

\section{Kesimpulan dan Saran}

Berdasarkan hasil penelitian dan temuan-temuan yang dikemukakan pada bab sebelumnya maka dapat disimpulkan:

1. Terdapat pengaruh yang signifikan setelah diberikan perlakuan manipulasi effleurage, petrissage, shaking, dan tapotement 6 jam setelah aktivitas eksentrik terhadap penurunan intensitas nyeri pada jam ke 24

2. Tidak terdapat perbedaan yang signifikan antar kelompok perlakuan manipulasi effleurage, petrissage, shaking, dan tapotement 6 jam setelah aktivitas eksentrik terhadap intensitas nyeri pada jam ke 24.

Berdasarkan hasil penelitian yang ada, maka disarankan:

1. Perlu dilakukan penelitian kembali pada sampel yang lebih besar, pada masing-masing variabel independen yaitu kelompok manipulasi effleurage, petrissage, shaking, dan tapotement, sehingga efek fisiologisnya akan terlihat lebih nyata

2. Perlu dilakukan uji perbandingan (komparasi) pada kelompok masingmasing manipulasi dari sport massage dengan kelompok tanpa perlakuan serta dengan kelompok perlakuan dengan manipulasi lengkap

\section{DAFTAR PUSTAKA}

Aslani, Marily. 2003. Teknik Pijat Untuk Pemula. Jakarta: Erlangga

Arovah, Intan Novita. 2011. Masase dan Prestasi Atlet. (Online), http://staff.uny.ac.id/sites/default/files/ 132300162/4.\%20Masase\%20dan\%20 Prestasi\%20Atlet.pdf, diakses pada 9 Januari 2013

Bubbico A and Kravitz L, 2010. Eccentric Exercise: a Comprehensive Review of a Distinctive Training Method. IDEA Fitness Journal. 7 50-59.

Burnley DE, Angela NO, Sharp RL, Bailer SW, Alekel DL, 2010. Impact of Protein Suplements on Muscle Recovery After Exercise-Induced Muscle Soreness. Journal Exercise Science Fitness. 8: 89-96.

Byrne C, Twist C, Eston R, 2004. Neuromuscular Function After Exercise Induced Muscle Damage: Theoritical and Applied Implications. Journal Sport Medicine. 34: 49-69.

Callaghan, M. J. (1993). The role of massage in the management of the athlete: a review. British Medical Journal 27(1): 28.

Clarson PM, Hubal MJ, 2008. Exercise Induced Muscle Damage in Humans. Journal Physiology Medical Rehabilitation. 81: 52-69.

Clarkson PM, Hubal MJ. Exercise-induced muscle damage in humans. Am J Phys Med Rehabil 2002; 81: S52-69

Ganong, William F. (1990). Buku Ajar Fisiologi Kedokteran. Jakarta: Penerbit Buku Kedokteran EGC

Giam C.K, dan Teh, K.C. (1993). Ilmu Kedokteran Olahraga (Hartono Satmoko. Terjemahan). Jakarta: Binarupa Aksara Buku asli diterbitkan tahun 1992.

Guyton AC, Hall JE, 2006. Texbook of Medical Physiology. Philadelphia: WB Saunders Company.

Moraska, A. (2005). Sports massage. The Journal of sports medicine and physical fitness 45: 370. 
Robertson A, Watt JM, Galloway SD (2004). Effects of leg massage on recovery from high intensity cycling exercise. British Journal of Sports Medicine, 38: 173-176.

Smletzer, \& Bare. (2002). Buku Ajar Keperawatan medikal-bedah Brunner \& Suddart Edisi 8 Vol. 1. jakarta: Buku Kedokteran EGC

Smith, Lucille L. The Effects of Athletic Massage on Delayed Onset Muscle Soreness, Creatine Kinase, and Neutrophil Count: A Preliminary Report. Journal of Orthopaedic \& Sports Physical Therapy: JOSPT Volume 19 Number 2 February 1994

Trenell MI, Rooney KB, Sue CM, Thompson CH, 2006. Compression Garments and Recovery from Eccentric Exercise: A P-MRS Study. Journal of Sports Science and Medicine. 5: 106-114.

Purwanto B. 2013. Mekanisme Kerja Curcumin Dalam Mencegah Kerusakan Otot Rangka Mencit Yang Melakukan Aktivitas Eksentrik Sesaat. Disertasi Fakultas Kedokteran Univ. Airlangga.Surabaya

Potter, P. A., \& Perry, A. G. (2005). Buku Ajar Fundamental Keperawatan Edisi 4. Jakarta: EGC.

Willoughby DS, Clesivanenk, Lemuel Taylor. 2003. Effects of Concentric and Eccentric Contractions on Exercise- Induced Muscle Injury, Inflamation and Serum IL-6. Journal of The American Society of Exercise Physiologists. Vol 6. 